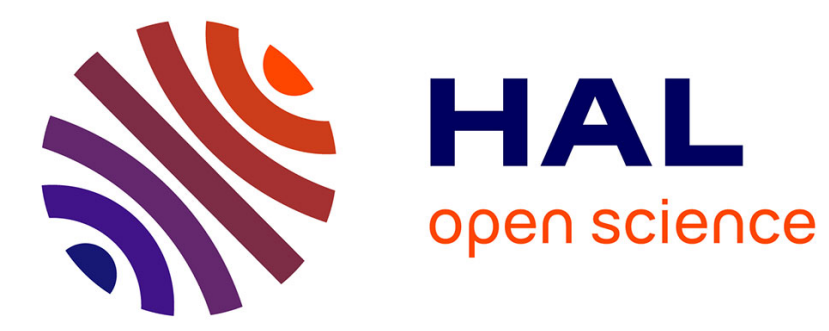

\title{
Characterization of EUV periodic multilayers
}

K. Le Guen, M.-H. Hu, J.-M. André, Philippe Jonnard, Z.-S. Wang, J.-T.

Zhu, A. Galtayries, C. Meny, Evgueni Meltchakov, Christophe Hecquet, et al.

\section{To cite this version:}

K. Le Guen, M.-H. Hu, J.-M. André, Philippe Jonnard, Z.-S. Wang, et al.. Characterization of EUV periodic multilayers. X-Ray Spectrometry, 2011, 40, pp.338. 10.1002/xrs.1350 . hal-00642782

\section{HAL Id: hal-00642782 \\ https://hal.science/hal-00642782}

Submitted on 18 Nov 2011

HAL is a multi-disciplinary open access archive for the deposit and dissemination of scientific research documents, whether they are published or not. The documents may come from teaching and research institutions in France or abroad, or from public or private research centers.
L'archive ouverte pluridisciplinaire HAL, est destinée au dépôt et à la diffusion de documents scientifiques de niveau recherche, publiés ou non, émanant des établissements d'enseignement et de recherche français ou étrangers, des laboratoires publics ou privés. 


\title{
Characterization of EUV periodic multilayers
}

\author{
K. Le Guen ${ }^{1}$, M.-H Hu ${ }^{1}$, J.-M. André ${ }^{1}$, P. Jonnard ${ }^{1}$, Z. Wang ${ }^{2}$, J. Zhu ${ }^{2}$,

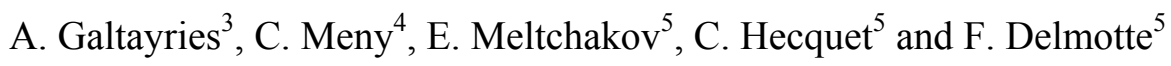 \\ ${ }^{1}$ Laboratoire Chimie Physique - Matière Rayonnement, UPMC CNRS UMR 7614, Paris, France \\ ${ }^{2}$ Institute of Precision Optical Engineering, Dpt of Physics, Tongji University, Shanghai, P.R. China \\ ${ }^{3}$ Laboratoire de Physico-Chimie des Surfaces, ENSCP, Paris, France \\ ${ }^{4}$ Institut de Physique et Chimie des Matériaux, CNRS UMR 7504, Strasbourg, France \\ ${ }^{5}$ Laboratoire Charles Fabry de l'Institut d'Optique, CNRS, Univ Paris-Sud, Palaiseau, France
}

\section{Date: $2010,15^{\text {th }}$ of June}

!! This manuscript is intended for the special issue on EXRS2010 !!

\begin{abstract}
Nanometric $\mathrm{Co} / \mathrm{Mg}, \mathrm{Co} / \mathrm{Mg} / \mathrm{B}_{4} \mathrm{C}, \mathrm{Al} / \mathrm{SiC}$ and $\mathrm{Al} / \mathrm{Mo} / \mathrm{SiC}$ periodic multilayers deposited by magnetron sputtering are studied in order to correlate their optical performances in the extreme ultraviolet (EUV) range to their structural quality. To that purpose, our recently developed methodology based on high resolution x-ray emission spectroscopy (XES) and x-ray and EUV reflectometry is now extended to nuclear magnetic resonance (NMR) spectroscopy and time-of-flight secondary ions mass spectrometry (ToF-SIMS). The analysis of the Co L $\alpha \beta$ and $\mathrm{Mg} \mathrm{K} \beta$ emission spectra shows that the Co and $\mathrm{Mg}$ atoms within the multilayers are in a chemical state equivalent to that of the atoms in the pure Co and Mg references respectively. But NMR spectra give evidence for a reaction between Co atoms and $\mathrm{B}$ and/or $\mathrm{C}$ atoms from $\mathrm{B}_{4} \mathrm{C}$. The $\mathrm{Al}$ and $\mathrm{Si} \mathrm{K} \beta$ emission spectra do not reveal the formation of an interfacial compound in $\mathrm{Al} / \mathrm{SiC}$ and $\mathrm{Al} / \mathrm{Mo} / \mathrm{SiC}$. Only the roughness limits the optical quality of $\mathrm{Al} / \mathrm{SiC}$. The comparative analysis of the ToF-SIMS spectra of $\mathrm{Al} / \mathrm{SiC}$ and $\mathrm{Al} / \mathrm{Mo} / \mathrm{SiC}$ indicates that the structural quality is enhanced when Mo is introduced within the stack.
\end{abstract}

Keywords: multilayers, interdiffusion, roughness, $\mathrm{x}$-ray, extreme UV 


\section{Introduction}

Nanometric periodic multilayers are used as optical components in the x-rays and extreme UV (EUV) spectral ranges for applications such as spatial telescopes, $\mathrm{x}$-rays microscopes, EUV photolithography or synchrotron beamlines. Their optical performances highly depend on the quality of the interfaces between the different layers within the stack. Both interdiffusion and geometrical roughness modify the optical properties at the application wavelength and therefore can lower the reflectance.

The aim of the present paper is to propose a way to disentangle interdiffusion and geometrical roughness in order to correlate the multilayer optical performances to its structural quality. To that purpose, we have recently developed a methodology coupling high resolution x-ray emission spectroscopy (XES) and x-ray and EUV reflectometry [1-4]. Nevertheless, in the case of the $\mathrm{Co} / \mathrm{Mg}$, $\mathrm{Co} / \mathrm{Mg} / \mathrm{B}_{4} \mathrm{C}, \mathrm{Al} / \mathrm{SiC}$ and $\mathrm{Al} / \mathrm{Mo} / \mathrm{SiC}$ multilayers, the sensitivity limit of this methodology appears to be reached, which does not allow us to firmly conclude. Complementary investigations are thus required. We have explored alternative experimental techniques, namely nuclear magnetic resonance (NMR) spectroscopy and time-of-flight secondary ions mass spectrometry (ToF-SIMS), to refine the stack structural description initiated by the XES and reflectivity measurements.

\section{Experiment}

\subsection{Multilayer deposition}

All the periodic multilayers were prepared using magnetron sputtering working with Ar gas. The samples were deposited onto ultra-smooth polished Si substrates with rms surface roughness of $0.3 \mathrm{~nm}$. The $\mathrm{Co} / \mathrm{Mg}$ and $\mathrm{Co} / \mathrm{Mg} / \mathrm{B}_{4} \mathrm{C}$ multilayers were deposited at the IPOE in Shanghai with targets of Co (purity 99.95\%), $\mathrm{Mg}$ (purity 99.98\%) and $\mathrm{B}_{4} \mathrm{C}$ (purity 99.5\%) in $\mathrm{Ar}$ gas (99.999\%). The power applied on the $\mathrm{Co}, \mathrm{Mg}$ and $\mathrm{B}_{4} \mathrm{C}$ targets was 25,15 and $80 \mathrm{~W}$ respectively. The $\mathrm{Al} / \mathrm{SiC}$ and $\mathrm{Al} / \mathrm{Mo} / \mathrm{SiC}$ multilayers were prepared at the Institut d'Optique in Palaiseau. The sputtering targets $(99.95 \%$ or higher purity) are $\mathrm{Mo}, \mathrm{SiC}$ and $\mathrm{Al}$ with $1.5 \mathrm{wt} \% \mathrm{Si}$. The $\mathrm{Al}$ and $\mathrm{SiC}$ targets were operated in rf-mode with applied power of $150 \mathrm{~W}$ and the Mo target was utilized in dc-mode $(0.05 \mathrm{~A})$. The name assignment and description of all the samples are given below:

- Co/Mg: Si substrate / [Co $(2.55 \mathrm{~nm}) / \mathrm{Mg}(14.45 \mathrm{~nm})]_{30} / \mathrm{B}_{4} \mathrm{C}(3.50 \mathrm{~nm})$

- $\mathrm{Co} / \mathrm{Mg} / \mathrm{B}_{4} \mathrm{C}:$ Si substrate / [Co $\left.(2.55 \mathrm{~nm}) / \mathrm{Mg}(14.45 \mathrm{~nm}) / \mathrm{B}_{4} \mathrm{C}(0.90 \mathrm{~nm})\right]_{30} / \mathrm{B}_{4} \mathrm{C}(2.60 \mathrm{~nm})$

- $\mathrm{Al} / \mathrm{SiC}: \mathrm{Si}$ substrate / $[\mathrm{Al}(13.4 \mathrm{~nm}) / \mathrm{SiC}(4.0 \mathrm{~nm})]_{40}$ 
- $\mathrm{Al} / \mathrm{Mo} / \mathrm{SiC}: \mathrm{Si}$ substrate / $[\mathrm{Al}(11.2 \mathrm{~nm}) / \mathrm{Mo}(1.7 \mathrm{~nm}) / \mathrm{SiC}(3.5 \mathrm{~nm})]_{15}$

The role of the $\mathrm{B}_{4} \mathrm{C}(\mathrm{SiC})$ top layer in the $\mathrm{Co} / \mathrm{Mg}$ and $\mathrm{Co} / \mathrm{Mg} / \mathrm{B}_{4} \mathrm{C}(\mathrm{Al} / \mathrm{SiC}$ and $\mathrm{Al} / \mathrm{Mo} / \mathrm{SiC}$ ) multilayers is to prevent, or at least minimize, the oxidation process. The choice of the Al target doped with $1.5 \mathrm{wt} \% \mathrm{Si}$ was done with the purpose to decrease the roughness of the Al layers [5]. The effective layer thicknesses of the deposited multilayers are controlled through x-ray reflectometry (XRR) using the $\mathrm{Cu} \mathrm{K \alpha}$ emission $(0.154 \mathrm{~nm}$ or $8048 \mathrm{eV})$ and performed with a grazing-incidence reflectometer working in the $\theta-2 \theta$ mode. The fit of these reflectivity curves allows the estimation of the stack structural parameters (thickness, roughness and density of each layer). The rms roughness values are collected in Table 1.

Table 1: Values of the rms roughness extracted from the fit of the XRR curves.

\begin{tabular}{|l|c|c|c|c|}
\hline$\sigma(\mathrm{nm})$ & Mg-on-Co & $\mathrm{B}_{4} \mathrm{C}$-on-Mg & Co-on- ${ }_{4} \mathrm{C}$ & Co-on-Mg \\
\hline $\mathrm{Co} / \mathrm{Mg}$ & 0.4 & - & - & 0.4 \\
\hline $\mathrm{Co} / \mathrm{Mg} / \mathrm{B}_{4} \mathrm{C}$ & - & - & - & - \\
\hline & $\mathrm{SiC}-$-on-Al & Mo-on-Al & SiC-on-Mo & Al-on-SiC \\
\hline $\mathrm{Al} / \mathrm{SiC}$ & 1.2 & - & - & 2.8 \\
\hline $\mathrm{Al} / \mathrm{Mo} / \mathrm{SiC}$ & - & 1.1 & 0.9 & 0.6 \\
\hline
\end{tabular}

In $\mathrm{Co} / \mathrm{Mg}$, the two interfaces appear to be symmetrical. The fit results of the $\mathrm{Co} / \mathrm{Mg} / \mathrm{B}_{4} \mathrm{C}$ x-ray curve are not presented in Table 1 since only 5 five intense and well-defined Bragg peaks are measured. It is striking that the introduction of Mo as a third material into the $\mathrm{Al} / \mathrm{SiC}$ multilayer basic design has resulted in decreasing roughness at all interfaces (by a factor 4.7 at the Al-on-SiC interface and by a factor 1.3 at the SiC-on-Mo interface) although Mo is introduced only at the SiC-on-Al interface.

\subsection{EUV reflectivity}

The EUV reflectivity curves are measured on the BEAR beamline [6] at the Elettra synchrotron source using $s$-polarized light. The photon energy is carefully calibrated using the $\mathrm{Pt} 4 \mathrm{f}_{7 / 2}$ feature and the Si L edge. The goniometer angular resolution is $1 / 100^{\circ}$. The intensities of incident and reflected light are measured with a solid state photodiode. The incoming photon flux is also monitored by measuring the drain current of an $\mathrm{Au}$ mesh inserted in the beam path. The overall accuracy of the absolute reflectivity values is estimated to be about $1 \%$.

\section{$2.3 \mathrm{X}$-ray emission spectroscopy}

XES is performed using a high-resolution wavelength dispersive soft X-ray spectrometer [7]. The measured emissions are: 
- the Co $\operatorname{L} \alpha \beta$ (3d-2 $\mathrm{p}_{3 / 2}$ and $3 \mathrm{~d}-2 \mathrm{p}_{1 / 2}$ transitions) and $\operatorname{Mg~K} \beta$ (Mg 3p - 1s transition) emissions originating respectively from the cobalt and magnesium atoms present in the $\mathrm{Co} / \mathrm{Mg}$ and $\mathrm{Co} / \mathrm{Mg} / \mathrm{B}_{4} \mathrm{C}$;

- the $\mathrm{Si} \mathrm{K} \beta$ (Si $3 p$ - 1s transition) and $\mathrm{Al} \mathrm{K} \beta$ (Al 3p - 1s transition) emissions originating respectively from the silicon and aluminum atoms present in the $\mathrm{Al} / \mathrm{SiC}$ and $\mathrm{Al} / \mathrm{Mo} / \mathrm{SiC}$.

The Co L $\alpha \beta$, Mg K $\beta$, Si K $\beta$ and Al K $\beta$ emission spectra respectively correspond to the distribution of the occupied valence states of the $\mathrm{Co}, \mathrm{Mg}, \mathrm{Si}$ and $\mathrm{Al}$ atoms present within the stack. Since valence electrons are the most weakly bound, the emission band is very sensitive to the physico-chemical environment of the emitting atoms.

The core holes are created by an electron beam coming from a Pierce gun. The energy of the incident electrons is set to 7.5 and $3.5 \mathrm{keV}$ for the $\mathrm{Mg} \mathrm{K} \beta$ and the $\mathrm{Co} L \alpha \beta$ emissions respectively, and 7 $\mathrm{keV}$ for the $\mathrm{Si}$ and $\mathrm{Al} \mathrm{K} \beta$ emissions respectively. Following the ionization of the atoms present in the sample, characteristic X-rays are emitted [8,9], then dispersed by a (001) TlAP (Co L $\alpha \beta$ emission), (10 10 ) beryl (Mg K $\beta$ emission), (111) InSb (Si K $\beta$ emission) or (10 $\overline{1} 0)$ quartz ( $\mathrm{Al} \mathrm{K} \beta$ emission) bent crystal and detected in a gas-flux counter working in the Geiger regime. The current density of the electrons reaching the sample is set to less than $1 \mathrm{~mA} \cdot \mathrm{cm}^{-2}$ to ensure that the shape and intensity of the studied emission band remain constant throughout the measurements.

Each emission spectrum is normalized with respect to its maximum and a linear background corresponding to the Bremsstrahlung contribution is subtracted. To determine the composition of the multilayer (especially to identify possible interfacial compounds), its emission spectrum is compared to that of reference compounds. This methodology is now routinely used to study complex materials, particularly various thin films and nanometric multilayers [10-17].

\subsection{Nuclear magnetic resonance spectroscopy}

The $\mathrm{Co} / \mathrm{Mg}$ and $\mathrm{Co} / \mathrm{Mg} / \mathrm{B}_{4} \mathrm{C}$ multilayers are analyzed by zero field NMR spectroscopy at $4.2 \mathrm{~K}$ using a homemade automated broadband spectrometer. The NMR spectra represent the distribution of the Co atoms as a function of their resonance frequency, that is to say the hyperfine field experienced by the Co nuclei $[18,19]$. The NMR resonance frequency is sensitive to the local environment of the probed (magnetic) atoms: nearest neighbor local structure and/or local chemical environment. Bulk references consisting in $1 \% \mathrm{~B}$ and $1 \% \mathrm{Mg}$ into Co are measured to check the influence of the $\mathrm{B}$ and $\mathrm{Mg}$ 
neighborhood on the Co resonance frequency (hyperfine field), giving rise to NMR lines at 117 and $170 \mathrm{MHz}$ respectively. For each spectrum, the total surface area of the sample is normalized to unity.

\subsection{Time-of-flight secondary ion mass spectrometry}

The depth distribution of the $\mathrm{Al} / \mathrm{SiC}$ and $\mathrm{Al} / \mathrm{Mo} / \mathrm{SiC}$ multilayers is measured using ToF-SIMS with the instrument working in the dual beam mode. The sputtering is performed using a $1 \mathrm{keV} \mathrm{Cs}^{+}$ion beam (current equal to $50 \mathrm{nA}$ ) scanning a $250 \mu \mathrm{m} \times 250 \mu \mathrm{m}$ area. The analysis beam consists in a $25 \mathrm{keV}$ primary $\mathrm{Bi}^{+}$ion source (current equal to $14 \mathrm{nA}$ ) scanning a $100 \mu \mathrm{m} \times 100 \mu \mathrm{m}$ area. Both ion beams are aligned in such a way that the analyzed ions originate from the centre of the sputtered crater. Both positive and negative ions are recorded. We have to keep in mind that the sputtering yields are not well-known and can vary drastically: (i) from one element to another and (ii) for a given element, from a chemical environment to another (for example, from the center of a layer to the interface with the neighboring layer). Consequently, (i) the sputtering time scale cannot be easily converted into a thickness scale and (ii) the intensity of the profile cannot be related to the number of atoms.

\section{Results and discussion}

\section{$\underline{3.1 \text { EUV reflectometry }}$}

The comparison between measured and simulated EUV peak reflectivity values is presented in Table 2 for the four multilayers. IMD reflectivity simulations [20] are performed assuming an "ideal" multilayer (neither roughness nor chemical reaction at the interfaces) and using $s$-polarized light incoming at $45^{\circ}$ for $\mathrm{Co} / \mathrm{Mg}$ and $\mathrm{Co} / \mathrm{Mg} / \mathrm{B}_{4} \mathrm{C}$ and $10^{\circ}$ from normal incidence for the $\mathrm{Al} / \mathrm{SiC}$ and $\mathrm{Al} / \mathrm{Mo} / \mathrm{SiC}$.

Table 2: Comparison of measured and simulated peak reflectivity values. In IMD simulations, an "ideal" multilayer (neither roughness nor chemical reaction at the interfaces) is considered.

\begin{tabular}{|c|c|c|c|}
\hline Multilayer & Grazing incidence $^{\circ}{ }^{\circ}$ & $\mathrm{R}_{\exp }$ & $\mathrm{R}_{\text {ideal }}$ \\
\hline $\mathrm{Co} / \mathrm{Mg}$ & 45 & $42.6 \% @ 25.1 \mathrm{~nm}$ & $56.5 \% @ 25.2 \mathrm{~nm}$ \\
\hline $\mathrm{Co} / \mathrm{Mg} / \mathrm{B}_{4} \mathrm{C}$ & 45 & $0.7 \% @ 25.1 \mathrm{~nm}$ & $53.5 \% @ 25.8 \mathrm{~nm}$ \\
\hline $\mathrm{Al} / \mathrm{SiC}$ & 80 & $7.4 \% @ 31.6 \mathrm{~nm}$ & $34.2 \% @ 31.8 \mathrm{~nm}$ \\
\hline $\mathrm{A} 1 / \mathrm{Mo} / \mathrm{SiC}$ & 80 & $28.5 \% @ 30.2 \mathrm{~nm}$ & $42.4 \% @ 30.2 \mathrm{~nm}$ \\
\hline
\end{tabular}

The discrepancy between the measured and simulated values can be ascribed to the interfacial roughness and/or the formation of interfacial compounds. To disentangle these two possible origins, in the next 
paragraph, we present the analysis of the XES spectra. If no chemical reaction at the multilayer interfaces can be evidenced, only the interfacial roughness is responsible for the reflectivity loss.

\section{$\underline{3.2 \mathrm{XES}: \mathrm{Co} / \mathrm{Mg}, \mathrm{Co} / \mathrm{Mg} / \mathrm{B}_{4} \underline{\mathrm{C}}, \mathrm{Al} / \mathrm{SiC} \text { and } \mathrm{Al} / \mathrm{Mo} / \mathrm{SiC} \text { multilayers }}$}

Figures 1(a) and (b) present the $\mathrm{Co} L \alpha \beta$ and $\mathrm{Mg} \mathrm{K} \beta$ emission bands of the $\mathrm{Co} / \mathrm{Mg}$ and $\mathrm{Co} / \mathrm{Mg} / \mathrm{B}_{4} \mathrm{C}$ multilayers while Figures $1(\mathrm{c})$ and (d) show the $\mathrm{Si}$ and $\mathrm{Al} \mathrm{K} \beta$ emission bands of the $\mathrm{Al} / \mathrm{SiC}$ and $\mathrm{Al} / \mathrm{Mo} / \mathrm{SiC}$ multilayers respectively. In all the cases, the multilayer emission band is compared to that of a reference sample: a Co thin film for the Co L $\alpha \beta$ emission, the $\mathrm{Mg}$ metal for the $\mathrm{Mg} \mathrm{K} \beta$ emission, an amorphous $\mathrm{SiC}$ thin film for the $\mathrm{Si} \mathrm{K} \beta$ emission and an $\mathrm{Al}(1.5 \mathrm{wgt} \% \mathrm{Si}$ ) thin film for the $\mathrm{Al} \mathrm{K} \beta$ emission.
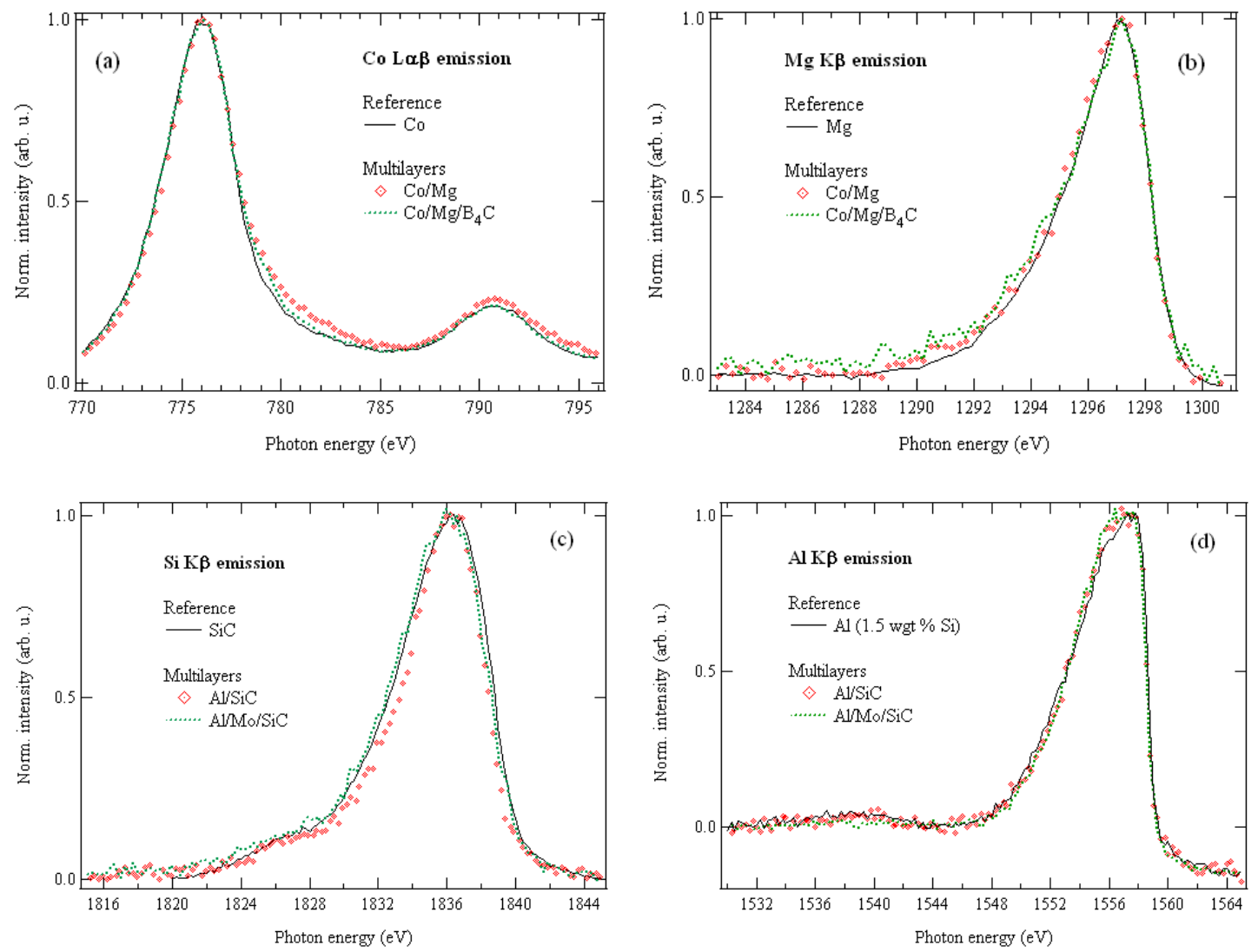

Figure 1: Emission bands originating from multilayers and reference compounds: (a) Co L $\alpha \beta$ emission, (b) $\mathrm{Mg} \mathrm{K} \beta$ emission, (c) Si K $\beta$ emission and (d) Al K $\beta$ emission.

The Co L $\alpha \beta$ and $\mathrm{Mg} \mathrm{K} \beta$ emission bands of the $\mathrm{Co} / \mathrm{Mg}$ and $\mathrm{Co} / \mathrm{Mg} / \mathrm{B}_{4} \mathrm{C}$ multilayers are discussed into details in Reference [21] and that of the $\mathrm{Si}$ and $\mathrm{Al} \mathrm{K} \beta$ emission bands in Reference [22]. In 
summary, in Figure 1(a), the $\mathrm{Co} L \alpha \beta$ emission bands of the $\mathrm{Co} / \mathrm{Mg}$ and $\mathrm{Co} / \mathrm{Mg} / \mathrm{B}_{4} \mathrm{C}$ multilayers are close to that of the Co reference. For the $\mathrm{Mg} \mathrm{K} \beta$ emission, Figure 1(b), the multilayers spectra are similar to that of the Mg metal. In Figure 1(c), the $\mathrm{Si} \mathrm{K} \beta$ emission band of the $\mathrm{Al} / \mathrm{SiC}$ and $\mathrm{Al} / \mathrm{Mo} / \mathrm{SiC}$ multilayers closely resembles that of the $\mathrm{SiC}$ reference while the $\mathrm{Al} \mathrm{K} \beta$ emission band of the $\mathrm{Al}$ (1.5 wgt $\% \mathrm{Si}$ ) reference in Figure 1(d) is quite identical to that of the $\mathrm{Al} / \mathrm{SiC}$ and $\mathrm{Al} / \mathrm{Mo} / \mathrm{SiC}$ multilayers.

In our recent study of Al-Mg alloys [23], the presence of at least $10 \mathrm{wgt} \%$ of $\mathrm{Al}(\mathrm{Mg})$ into $\mathrm{Mg}$ (Al) is enough to significantly change the shape of the $\mathrm{Mg} \mathrm{K} \beta$ ( $\mathrm{Al} \mathrm{K} \beta$ ) emission band and to allow the identification of an intermetallic compound $\left(\mathrm{Al}_{3} \mathrm{Mg}_{2}\right.$ or $\left.\mathrm{Al}_{12} \mathrm{Mg}_{17}\right)$ formed within the alloy. Moreover, in our studies of the $\mathrm{Mo} / \mathrm{Si}$ multilayers [2,3] and of the annealing of the $\mathrm{Mg} / \mathrm{SiC}$ multilayers [24], the analysis of the shape of the $\mathrm{Si} K \beta$ emission band allowed us to evidence the formation of an interfacial compound which thickness is equal or lower than $1 \mathrm{~nm}$. Thus, for the $\mathrm{Mg}, \mathrm{Al}$ and $\mathrm{Si} \mathrm{K} \beta$ emissions, the sensitivity of the technique towards the $\mathrm{p}$ valence states is high.

These results enable us draw the following conclusions: (i) in $\mathrm{Co} / \mathrm{Mg}$ and $\mathrm{Co} / \mathrm{Mg} / \mathrm{B}_{4} \mathrm{C}$, the $\mathrm{Mg}$ atoms are in a physico-chemical state close to that of the $\mathrm{Mg}$ atoms in pure $\mathrm{Mg}$ metal and (ii) in $\mathrm{Al} / \mathrm{SiC}$ and $\mathrm{Al} / \mathrm{Mo} / \mathrm{SiC}$ the $\mathrm{Si}$ and $\mathrm{Al}$ atoms are in a physico-chemical state close to that of the $\mathrm{Si}$ and $\mathrm{Al}$ atoms in the $\mathrm{SiC}$ and $\mathrm{Al}$ with $1.5 \mathrm{wgt} \%$ of $\mathrm{Si}$ references respectively. Thus, the interdiffusion can be unambiguously excluded in $\mathrm{Al} / \mathrm{SiC}$ and $\mathrm{Al} / \mathrm{Mo} / \mathrm{SiC}$ while in $\mathrm{Co} / \mathrm{Mg}$ and $\mathrm{Co} / \mathrm{Mg} / \mathrm{B}_{4} \mathrm{C}$, we can only assert that the $\mathrm{Mg}$ atoms have not reacted. Indeed, the sensitivity of our XES analysis towards the Co $3 \mathrm{~d}$ states appears to be limited and prevents us from stating any firm conclusion concerning a possible reaction of the Co atoms. This limitation certainly originates from the localization of the $\mathrm{d}$ state wavefunction in the vicinity of the nucleus. Complementary experimental techniques are required to rule on the physicochemical state of the $\mathrm{Co}$ atoms and also to understand the higher reflectance of $\mathrm{Al} / \mathrm{Mo} / \mathrm{SiC}$ with respect to $\mathrm{Al} / \mathrm{SiC}$.

\section{$\underline{3.3 \mathrm{Co} / \mathrm{Mg} \text { and } \mathrm{Co} / \mathrm{Mg} / \mathrm{B}_{4} \mathrm{C} \text { multilayers: NMR spectroscopy }}$}

NMR spectra of the $\mathrm{Co} / \mathrm{Mg}$ and $\mathrm{Co} / \mathrm{Mg} / \mathrm{B}_{4} \mathrm{C}$ multilayers are presented in Figure 2. The $\mathrm{Co} / \mathrm{Mg}$ sample exhibits a well-defined line at $226 \mathrm{MHz}$ which is the signature of the bulk hop Co. Therefore, the Co atoms are mainly situated in pure Co layers and the intermixing at the interfaces remains limited. The additional line observed at $156 \mathrm{MHz}$ cannot be related to the $1 \% \mathrm{Mg}$ into Co reference sample $(170 \mathrm{MHz})$ which most probably corresponds to $\mathrm{Co}$ in a $\mathrm{Co}_{2} \mathrm{Mg}$ phase. Therefore the $156 \mathrm{MHz} \mathrm{NMR}$ 
line is likely to arise from Co situated at well defined $\mathrm{Co} / \mathrm{Mg}$ interfaces. In the $\mathrm{Co} / \mathrm{Mg} / \mathrm{B}_{4} \mathrm{C}$ spectrum, no Co bulk line is observed anymore. The Co layers are not pure and alien atoms ( $\mathrm{Mg}, \mathrm{B}$ or $\mathrm{C}$ ) are mixed with Co atoms. Since, from the XES analysis, no compound is formed at the $\mathrm{Co} / \mathrm{Mg}$ interface, the mixing in $\mathrm{Co} / \mathrm{Mg} / \mathrm{B}_{4} \mathrm{C}$ multilayers originates from the $\mathrm{Co} / \mathrm{B}_{4} \mathrm{C}$ interface. This intermixing is strong: the absolute integral intensity of the $\mathrm{Co} / \mathrm{Mg} / \mathrm{B}_{4} \mathrm{C}$ spectra is three times smaller than the intensity of the $\mathrm{Co} / \mathrm{Mg}$ spectra, meaning that two thirds of the total Co atoms included in the sample are not observed in the $\mathrm{Co} / \mathrm{Mg} / \mathrm{B}_{4} \mathrm{C}$ NMR spectra.

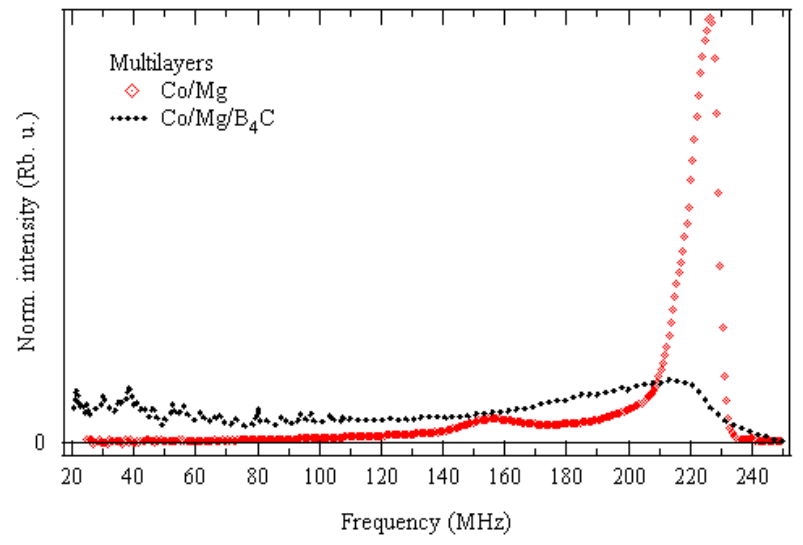

Figure 2: $\mathrm{Co} / \mathrm{Mg}$ and $\mathrm{Co} / \mathrm{Mg} / \mathrm{B}_{4} \mathrm{C}$ NMR spectra.

These Co atoms are most probably into a non-ferromagnetic phase with a large content of B and/or $\mathrm{C}$ atoms and therefore do not contribute to the NMR signal. The difference between the experimental and simulated reflectivity values in $\mathrm{Co} / \mathrm{Mg}$ can be ascribed only to the interfacial roughness since no compound formation is evidenced. In contrast, in $\mathrm{Co} / \mathrm{Mg} / \mathrm{B}_{4} \mathrm{C}$, it is observed that the Co atoms react with the $\mathrm{B}$ or $\mathrm{C}$ atoms of the carbide layers to form an interfacial compound while the $\mathrm{Mg}$ atoms remain undisturbed. Therefore, the low reflectance originates from both interdiffusion and roughness. Fitting the corresponding x-ray curve, it turns out that a three-layer model fails to describe this stack. Concerning the Co L $\alpha \beta$ emission band of $\mathrm{Co} / \mathrm{Mg} / \mathrm{B}_{4} \mathrm{C}$ (sub-section 3.2), the sensitivity limit of the XES technique to the Co $3 \mathrm{~d}$ states did not allow us to evidence this intermixing.

\section{$\underline{3.4 \mathrm{Al} / \mathrm{SiC} \text { and } \mathrm{Al} / \mathrm{Mo} / \mathrm{SiC} \text { multilayers: ToF-SIMS measurements }}$}

The depth distribution of the $\mathrm{Si}^{-}$and $\mathrm{Al}^{-}$ions originating from the $\mathrm{Al} / \mathrm{Mo} / \mathrm{SiC}$ multilayer, analyzed down to the substrate, is shown on a logarithmic scale in Figure 3(a). The italic numbers from 1 to 15 refer to the trilayer order counted from the surface. For sake of clarity, we do not show the $\mathrm{C}^{-}$ 
profile since it is observed that it closely follows that of $\mathrm{SiC}^{-}$. The 15 periods of the stack are clearly identified from the signal periodic oscillations.
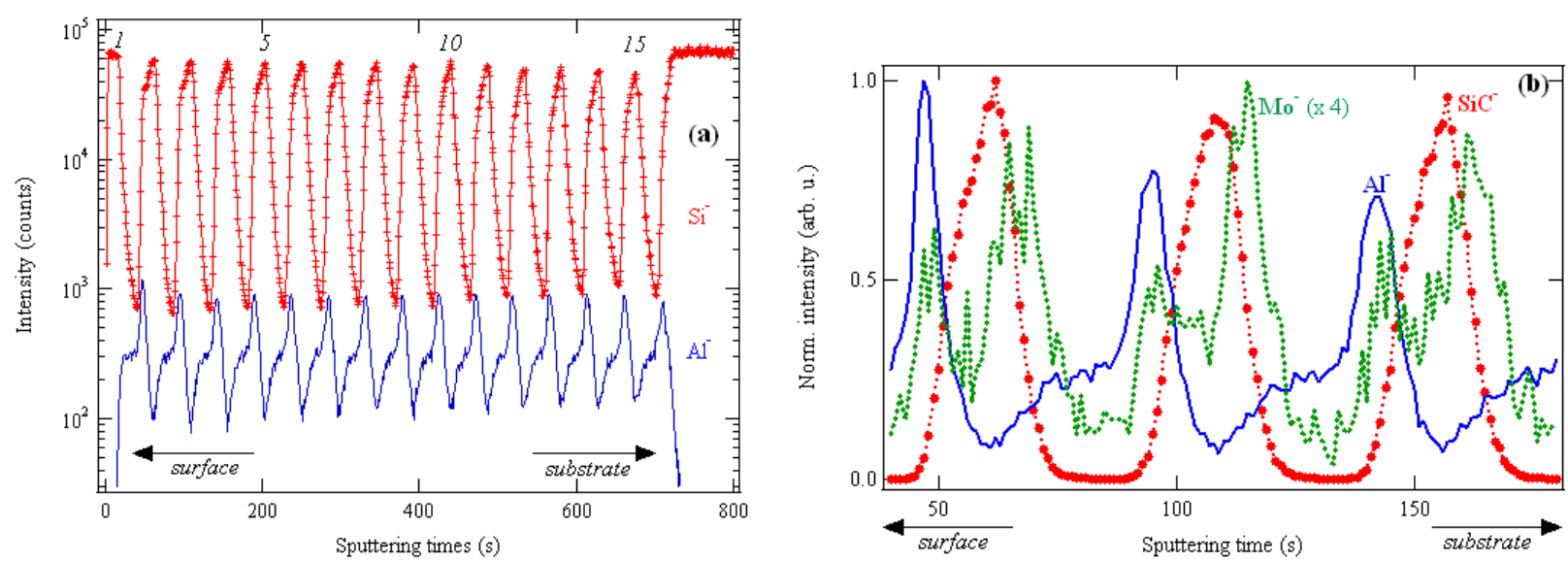

Figure 3: (a) $\mathrm{Al}^{-}$and $\mathrm{Si}^{-}$ion depth distribution of the $\mathrm{Al} / \mathrm{Mo} / \mathrm{SiC}$ multilayer; (b) $\mathrm{SiC}^{-}, \mathrm{Al}^{-}$and $\mathrm{Mo}^{-}$ion depth distributions of the $2^{\text {nd }}, 3^{\text {rd }}$ and $4^{\text {th }}$ periods of $\mathrm{Al} / \mathrm{Mo} / \mathrm{SiC}$. For the sake of comparison, the $\mathrm{Mo}^{-}$ profile intensity has been multiplied by a factor 4 .

In Figure 3(b), we present on a linear scale the $\mathrm{SiC}^{-}, \mathrm{Al}^{-}$and $\mathrm{Mo}^{-}$ion depth profiles from the second, third and fourth periods of $\mathrm{Al} / \mathrm{Mo} / \mathrm{SiC}$. The asymmetrical shape of the profile (particularly in the case of $\mathrm{Al}^{-}$and $\mathrm{Mo}^{-}$) cannot be related to a gradient of the atom number within the layer. In fact, since the layer thickness is small, a steady sputtering regime has not enough time to be established before the end of the layer erosion. In addition, as mentioned above, large variations of the sputtering yield occur at interfaces leading for example to the sharp maximum of the $\mathrm{Al}^{-}$profile. Thus, in a given profile, if we consider that the center of a layer corresponds approximately to the end of the plateau just before the intensity maximum, the right order of the layers is found, i.e. from the substrate: $\mathrm{Al}, \mathrm{Mo}$, and then $\mathrm{SiC}$ [25].

The comparison of the $\mathrm{Si}^{+}$ion depth distribution in the $\mathrm{Al} / \mathrm{SiC}$ and $\mathrm{Al} / \mathrm{Mo} / \mathrm{SiC}$ multilayers is presented in Figure 4. 


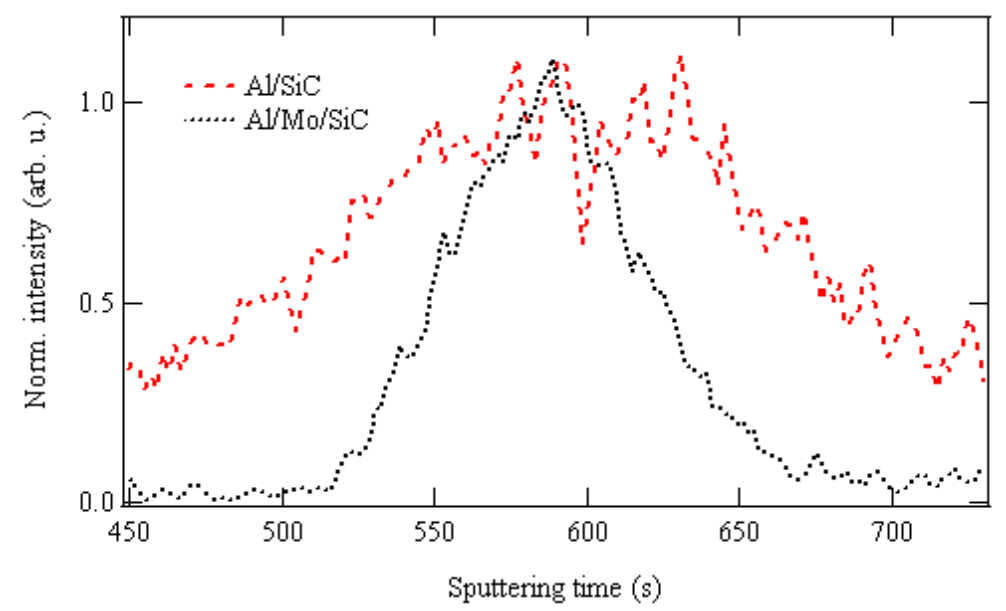

Figure 4: Comparison of the $\mathrm{Si}^{+}$ion depth distribution in the $\mathrm{Al} / \mathrm{SiC}$ and $\mathrm{Al} / \mathrm{Mo} / \mathrm{SiC}$ multilayers. The profiles have been shifted in time in order to align their respective maximum and only one period is presented.

Both positive and negative slopes of the profile in $\mathrm{Al} / \mathrm{Mo} / \mathrm{SiC}$ are much steeper than those in $\mathrm{Al} / \mathrm{SiC}$. The same effect is reported for $\mathrm{Al}^{+}$(not shown) [22]. The steeper is the slope, the more abrupt is the interface. This gives evidence for better defined $\mathrm{Al}$ and $\mathrm{SiC}$ layers and more abrupt interfaces when Mo is introduced as a third material within the multilayer structure, in good agreement with the XRR measurements.

\section{Conclusion}

We have performed x-ray emission and reflectivity measurements to access the structural description of the $\mathrm{Co} / \mathrm{Mg}, \mathrm{Co} / \mathrm{Mg} / \mathrm{B}_{4} \mathrm{C}, \mathrm{Al} / \mathrm{SiC}$ and $\mathrm{Al} / \mathrm{Mo} / \mathrm{SiC}$ multilayers. Since the sensitivity of the XES analysis restricts us to draw firm conclusions, we have resorted to complementary characterization techniques, namely NMR spectroscopy and ToF-SIMS.

Concerning the $\mathrm{Co} / \mathrm{Mg}$ and $\mathrm{Co} / \mathrm{Mg} / \mathrm{B}_{4} \mathrm{C}$ systems, a reflectivity value of 42.6 and $0.7 \%$ respectively is measured at $45^{\circ}$ of incidence at $25.1 \mathrm{~nm}$. The analysis of the Co $\mathrm{L} \alpha \beta$ and $\mathrm{Mg} \mathrm{K} \beta$ emission spectra shows that the $\mathrm{Co}$ and $\mathrm{Mg}$ atoms within the multilayers are in a chemical state equivalent to that of the atoms in the pure $\mathrm{Co}$ and $\mathrm{Mg}$ references respectively. However, the NMR spectra give evidence of a reaction between Co atoms and $\mathrm{B}$ and/or $\mathrm{C}$ atoms from $\mathrm{B}_{4} \mathrm{C}$. In $\mathrm{Co} / \mathrm{Mg}$, the interfaces do not present any interdiffusion and only the roughness is responsible for the difference 
between the measured and simulated reflectance values. In $\mathrm{Co} / \mathrm{Mg} / \mathrm{B}_{4} \mathrm{C}$, the low reflectance originates from both interdiffusion and roughness.

In the case of the $\mathrm{Al} / \mathrm{SiC}$ system, the introduction of a third layer material (Mo) reduces the roughness at all interfaces, leading to a reflectivity value equal to $28.5 \%$ at quasi-normal incidence at $30.2 \mathrm{~nm}$. The $\mathrm{Al}$ and $\mathrm{Si} \mathrm{K} \beta$ emission spectra do not reveal the formation of an interfacial compound in $\mathrm{Al} / \mathrm{SiC}$ and $\mathrm{Al} / \mathrm{Mo} / \mathrm{SiC}$. Thus we suppose that the geometrical roughness mainly limits the optical quality of $\mathrm{Al} / \mathrm{SiC}$. The comparative analysis of the ToF-SIMS spectra of $\mathrm{Al} / \mathrm{SiC}$ and $\mathrm{Al} / \mathrm{Mo} / \mathrm{SiC}$ indicates that the structural quality is enhanced when Mo is introduced within the stack.

Acknowledgements: S. Nannarone, A. Giglia and N. Mahne from the BEAR beamline at the ELETTRA synchrotron are thanked for their help during the measurements of EUV reflectivity. The authors from Tongji University are indebted to the National Natural Science Foundation of China (Granted No. 10825521). The work dealing with $\mathrm{Al} / \mathrm{SiC}$ and $\mathrm{Al} / \mathrm{Mo} / \mathrm{SiC}$ was funded by the $\mathrm{ANR}$ project 07-BLAN-0150. The deposition of $\mathrm{Al} / \mathrm{SiC}$ and $\mathrm{Al} / \mathrm{Mo} / \mathrm{SiC}$ has been carried out on the deposition machine of CEMOX (Centrale d'élaboration et de métrologie des optiques X) implemented at the Institut d'Optique by PRaXO (Pôle d'optique des Rayons X d'Orsay). 


\section{Références}

[1] P. Jonnard, I. Jarrige, R. Benbalagh, H. Maury, J.-M. André, Z. Dankhazi, G. Rolland, Surf. Science 2005, 589, 164

[2] H. Maury, P. Jonnard, J.-M. André, J. Gautier, M. Roulliay, F. Bridou, F. Delmotte, M.-F. Ravet, A. Jérome, P. Holliger, Thin Solids Films 2006, 514, 278

[3] H. Maury, P. Jonnard, J.-M. André, J. Gautier, F. Bridou, F. Delmotte, M.-F. Ravet, Surf. Sci. 2007, 601,2315

[4] K. Le Guen, H. Maury, J.-M. André, H. Wang, J. Zhu, Z. Wang, P. Jonnard, Appl. Surf. Sci. 2007, 253,8443

[5] E. Meltchakov, C. Hecquet, M. Roulliay, S. De Rossi, Y. Menesguen, A. Jérôme, F. Bridou, F. Varnière, M.-F. Ravet-Krill, F. Delmotte, Appl. Phys. A 2010, 98, 111

[6] S. Nannarone, F. Borgatti, A. DeLuisa, B.P. Doyle, G.C. Gazzadi, A. Giglia, P. Finetti, N. Mahne, L. Pasquali, M. Pedio, G. Selvaggi, G. Naletto, M.G. Pelizzo, G. Tondello, AIP Conference Proceedings 2004, 708, 450

[7] C. Bonnelle, F. Vergand, P. Jonnard, J.-M. André, P.F. Staub, P. Avila, P. Chargelègue, M.-F. Fontaine, D. Laporte, P. Paquier, A. Ringuenet, B. Rodriguez, Rev. Sci. Instrum. 1994, 65, 3466

[8] L.V. Azaroff,. “X-ray Spectroscopy”. McGraw-Hill Inc. 1974

[9] C. Bonnelle, X-ray spectroscopy. Annu. Rep. Prog. Chem., Sect. C, Phys. Chem. 1987, 84, 201

[10] M. Iwami, M. Kusaka, M. Hirai, R. Tagami, H. Nakamura, H. Watabe, Appl. Surf. Sci. 1997, 117, 434

[11] E.Z. Kurmaev, V.R. Galakhov, S.N. Shamin, Crit. Rev. Solid State Mater. Sci. 1998, 23, 65

[12] N. Miyata, S. Ishikawa, M. Yanagihara, M. Watanabe, Jap. J. of Appl. Phys. Part 1-Regular Papers Short Notes \& Review Papers 1999, 38, 6476

[13] I. Jarrige, P. Jonnard, N. Frantz-Rodriguez, K. Danaie, A. Bosseboeuf, Surf. and Interf. Anal. 2002, 34,694

[14] V.R. Galakhov, X-Ray Spectrom. 2002, 31, 203

[15] M. Salou, S. Rioual, J. Ben Youssef, D.T. Dekadjevi, S.P. Pogossian, P. Jonnard, K. Le Guen, G. Gamblin, B. Rouvellou, Surf. and Interf. Anal. 2008, 40, 1318

[16] K. Le Guen, G. Gamblin, P. Jonnard, M. Salou, J. Ben Youssef, S. Rioual, B. Rouvellou, Eur. Phys. J.-Appl. Phys. 2009, 45, 20502

[17] H. Maury, J.-M. André, K. Le Guen, N. Mahne, A. Giglia, S. Nannarone, F. Bridou, F. Delmotte, P. Jonnard, Surf. Sci. 2009, 603, 407

[18] C. Meny, P. Panissod, Modern Magnetic Resonance, G. Webb, Ed., Springer, Heidelberg, 2006 
[19] P. Panissod, C. Meny, Appl. Magn. Res. 2000, 19, 447

[20] D.L. Windt, Computers in Physics, 1998, 12, 360

[21] K. Le Guen, M.-H. Hu, J.-M. André, P. Jonnard, S. K. Zhou, H. Ch. Li, J. T. Zhu, Z. S. Wang, C. Meny, J. Phys. Chem. C, 2010, 114, 6484

[22] P. Jonnard, K. Le Guen, M.-H. Hu, E. Meltchakov, C. Hecquet, F. Delmotte, A. Galtayries, Proc. SPIE 2009, 7360, O1-9

[23] P. Jonnard, K. Le Guen, R. Gauvin et J.-F. Le Berre, Microsc. Microanal. 2009, 15, 36

[24] H. Maury, P. Jonnard, K. Le Guen, J.-M. André, Z. Wang, J. Zhu, J. Dong, Z. Zhang, F. Bridou, F. Delmotte, C. Hecquet, N. Mahne, A. Giglia, S. Nannarone, Eur. Phys. J. B 2008, 64, 193

[25] M.-H. Hu, K. Le Guen, J.-M. André, P. Jonnard, E. Meltchakov, F. Delmotte, A. Galtayries, in preparation 